\title{
HUBUNGAN DURASI AKTIVITAS FISIK DAN ASUPAN NATRIUM DENGAN TEKANAN DARAH PADA WANITA MENOPAUSE
}

\author{
Fitra Aprilindo Sase, Adriyan Pramono*) \\ Program Studi Ilmu Gizi Fakultas Kedokteran Universitas Diponegoro \\ Jl.Dr.Sutomo No.14, Semarang, Telp (024) 8453708, Email : gizifk@undip.ac.id
}

\begin{abstract}
Background: Menopausal women are susceptible to hypertension. Less estrogen can cause increased blood pressure. Lack of activity and high intake of sodium conducted to be suspect as factor causing increase blood pressure. This study aimed to determine the correlation of physical activity and sodium intake with blood pressure at menopausal women.

Methods: This study was cross-sectional design. Blood pressure data obtained from measurement using mercury sphygmomanometer by trained personnel. Duration physical activity data obtained from interview using questionnaire physical activity and sodium intake data obtained from interview using semi-quantitative FFQ.

Results: 65,2\% subjects are systolic pre-hypertension and 49,3\% subject are diastolic pre-hypertension. 14,5\% subjects are hypertension systolic and 36,2\% subjects are hypertension diastolic. 50,72\% subjects did physical activity $\geq 440$ minutes/week. There was no significant correlation $(p>0,05)$ of duration physical activity with systolic blood pressure $(r=-0,133 ; p=0,275)$ nor diastolic $(r=-0,075 ; p=0,541)$. There is a significant correlation $(p<0,05)$ of sodium intake with systolic blood pressure $(r=0,514 ; p=0,000)$,

Conclusion: There is a significant correlation of sodium intake with systolic blood pressure.
\end{abstract}

Keywords: menopause; blood pressure; physical activity; sodium intake

\begin{abstract}
ABSTRAK
Latar Belakang: Wanita menopause lebih rentan terhadap hipertensi. Hormon estrogen yang kurang dapat menyebabkan penyempitan pembuluh darah yang berakibat tekanan darah meningkat. Kurangnya aktivitas dan asupan tinggi natrium diduga sebagai faktor penyebab peningkatan tekanan darah. Penelitian ini bertujuan untuk mengetahui hubungan aktivitas fisik dan asupan natrium dengan tekanan darah pada wanita menopause.

Metode: Penelitian ini menggunakan desain cross-sectional. Data tekanan darah diperoleh dari pengukuran menggunakan sphygmomanometer air raksa oleh petugas terlatih. Data durasi aktivitas fisik diperoleh dengan wawancara menggunakan kuesioner aktivitas fisik dan data asupan natrium diperoleh dengan melakukan wawancara menggunakan FFQ semi kuantitatif.

Hasil: 65,2\% subjek pre-hipertensi sistolik dan 49,3\% subjek pre-hipertnsi diastolik. 14,5\% subjek hipertensi sistolik dan 36,2\% subjek hipertensi diastolik. 50,7\% subjek beraktivitas fisik $\geq 440$ menit/minggu. Tdiak terdapat hubungan bermakana $(p>0,05)$ duarasi aktivitas fisik dengan tekanan drah sistolik $(r=-0,133 ; p=0,275)$ maupun diastolik $(r=-0,75 ; p=0,541)$ Terdapat hubungan bermakna $(p<0,05)$ antara asupan natrium dengan tekanan darah sistolik $(r=0,015 ; p=0,000)$.
\end{abstract}

Simpulan: Terdapat hubungan bermakna asupan natrium dengan tekanan darah sistolik.

Kata Kunci: menopause; tekanan darah; aktivitas fisik; asupan natrium

\section{PENDAHULUAN}

Penyakit kardiovaskuler merupakan salah satu penyebab kematian terbesar didunia. Laporan WHO tahun 2008 menyebutkan 17,3 juta manusia meninggal akibat penyakit kardiovaskuler. Salah satu penyebab penyakit kardiovaskuler adalah hipertensi. ${ }^{1}$ Kejadian hipertensi pada wanita lebih tinggi dibanding pria berturut-turut $9,0 \%$ dan $6,1 \%{ }^{2}$ Wanita menopause lebih rentan terhadap hipertensi, hal ini disebabkan kurangnya hormon estrogen pada wanita menopause sehingga dapat menyebabkan penyempitan pembuluh darah yang berakibat tekanan darah meningkat. ${ }^{3}$

Peningkatan tekanan darah dipengaruhi berbagai macam faktor, diantaranya adalah kurangnya aktivitas fisik. Studi yang membandingkan beda efek intensitas olahraga menunjukkan olahraga dengan intensitas ringan hingga sedang lebih efektif menurunkan tekanan darah dibanding intensitas berat dan juga lebih efektif pada usia lanjut. ${ }^{4}$ Aktivitas fisik yang baik dan rutin akan melatih otot jantung dan menurunkan tahanan perifer yang dapat mencegah

\footnotetext{
${ }^{*}$ Penulis Penanggungjawab
} 
peningkatan tekanan darah. Disamping itu, olahraga yang teratur dapat merangsang pelepasan hormon endorfin yang menimbulkan efek euphoria dan relaksasi otot sehingga tekanan darah tidak meningkat. ${ }^{5}$ Kegiatan aktivitas fisik intensitas sedang dapat dicontohkan seperti bersepeda santai, jalan cepat (brisk walk), pekerjaan rumah tangga, dan lain-lain.

Selain aktivitas fisik, asupan zat gizi juga berpengaruh pada peningkatan tekanan darah. Salah satu zat gizi mikro yang berperan penting dalam peningkatan tekanan darah adalah natrium. Studi meta analisis menunjukkan hasil penurunan tekanan darah sistolik sebesar $4 \mathrm{mmHg}$ dan penurunan tekanan darah diastolik sebesar 2,5 $\mathrm{mmHg}$ setelah diturunkan asupan natrium sebesar 50 mmol. ${ }^{6}$ Natrium menyebabkan tubuh menahan air dengan tingkat melebihi ambang batas normal tubuh, sehingga dapat meningkatkan volume darah dan menyebabkan tekanan darah meningkat. ${ }^{7}$

Wanita menopause merupakan kelompok yang rentan terhadap kejadian hipertensi dan juga penyakit kardiovaskuler lainnya. Hal ini diperburuk lagi dengan kondisi menopause yang pada umumnya dimulai pada usia lansia awal dimana pada usia tersebut individu akan cenderung melakukan aktivitas fisik yang ringan, terjadinya perubahan komposisi tubuh, dan penurunan beberapa fungsi organ-organ tubuh seiring bertambahnya usia. ${ }^{8}$ Sebuah hasil penelitian pada lansia di Tasikmalaya menunjukkan bahwa lansia memiliki kebiasaan konsumsi natrium yang sering yaitu $73,7 \%$ (56 subjek dari 76), hal ini juga menjadi faktor risiko yang meningkatkan kejadian hipertensi pada wanita menopause, dengan ditunjukkan hasil subjek hipertensi terbanyak pada kelompok subjek sering konsumsi natrium yaitu 73,2\% (41 subjek dari 48 subjek hipertensi). ${ }^{9}$

Penelitian ini bertujuan untuk mengetahui hubungan durasi aktivitas fisik sedang, ringan, dan asupan natrium dengan tekanan darah pada wanita menopause.

\section{METODE PENELITIAN}

Penelitian dilakukan selama bulan Januari hingga bulan Febuari dikelompok pengajian Yamata dan Isy Karima di kota Solo, Jawa Tengah. Penelitian ini termasuk penelitian observasional dengan desain cross-sectional.

Populasi terjangkau penelitian ini adalah wanita menopause di kelompok pengajian Yamata dan Isy Karima di kota Solo. Subjek dalam penelitian ini sebanyak 69 orang. Metode pengambilan subjek adalah consecutive sampling, dan dipilih sesuai dengan kriteria inklusi yaitu sudah menopause, tidak mengkonsumsi obatobatan yang mempengaruhi tekanan darah, tidak menggunakan terapi hormon, tidak dalam kondisi sakit atau perawatan dokter, tidak memiliki kebiasaan merokok atau meminum alkohol, dan bersedia mengisi informed consent.

Data yang dikumpulkan dalam penelitian ini adalah gambaran umum subjek, durasi aktivitas fisik subjek, asupan natrium subjek, dan tekanan darah sistolik dan tekanan darah diastolik subjek. Variabel bebas dalam penelitian ini yaitu durasi aktivitas fisik dan asupan natrium dan variabel terikat yaitu tekanan darah sistolik dan tekanan darah diastolik.

Data durasi aktivitas fisik diperoleh dari hasil wawancara dengan subjek menggunakan instrumen kuesioner aktivitas fisik. Durasi aktivitas fisik yang dilaporkan oleh subjek mencakup durasi aktivitas fisik berat, sedang, dan ringan selama tujuh hari terakhir. Durasi aktivitas fisik berat sedang adalah waktu yang digunakan untuk melakukan kegiatan yang membutuhkan tenaga besar dan mebuat kerja pernafasan sangat cepat seperti senam aerobik, mengangkat beban yang berat, berlari, dan sebagainya yang dilakukan selama atau lebih dari 10 menit. Durasi aktivitas fsik sedang adalah waktu yang digunakan untuk melakukan kegiatan yang membutuhkan tenaga lebih dan mebuat kerja pernafasan lebih cepat seperti jalan cepat, senam, bersepada santai, pekerjaan rumah tangga, dan sebagainya yang dilakukan selama atau lebih dari 10 menit. Durasi aktivitas fisik ringan adalah waktu yang digunakan untuk melakukan kegiatan yang hanya memerlukan sedikit tenaga dan biasanya tidak menyebabkan perubahan dalam pernapasan seperti berjalan yang dilakukan selama atau lebih dari 10 menit. Skala variabel yang digunakan adalah skala rasio dengan satuan menit/minggu

Data Asupan natrium diperoleh dari hasil wawancara dengan subjek menggunakan instrumen Food Frequency Questioner (FFQ) semi kuantitatif. Data asupan natrium dapat dikategorikan menjadi 2 kategori yang mengacu pada $W H O$ yaitu asupan baik ( $<2400 \mathrm{mg} /$ hari) dan asupan tinggi ( $\geq 2400 \mathrm{mg} / \mathrm{hari}$ ) Skala variabel yang digunakan adalah skala rasio dan dinyatakan dalam satuan miligram per hari (mg/hari). Pengukuran tekanan darah dilakukan dengan menggunakan instrumen pengukuran yaitu sphygmomanometer dan dilakukan oleh petugas terlatih mengacu pada standar operasional prosedur pengukuran tekanan darah dalam buku standar asuhan keperawatan 
RSU Budi Luhur. ${ }^{10}$ Skala variabel yang digunakan adalah skala rasio yang dinyatakan dalam satuan mmHg.

Data-data yang sudah diolah akan dianalisis secara statistik menggunakan program uji statistik. Analisis univariat dilakukan untuk mendeskripsikan data karakteristik subjek, data durasi aktivitas fisik, data asupan natrium, data tekanan darah sistolik dan data tekanan darah

diastolik. Data tersebut diuji kenormalannya menggunakan uji Kolmogorov-Smirnov. Data yang berdistribusi normal disajiakan dalam bentuk rerata \pm SD sedangkan data yang berdistribusi tidak normal disajiakan dalam bentuk median. Analisis bivariat dilakukan dengan menggunakan uji korelasi rank Spearman. ${ }^{11}$

\section{HASIL PENELITIAN}

Tabel 1. Karakteristik subjek berdasarkan kategori usia, tingkat pendidikan, kategori tekanan darah sistolik dan diastolik, durasi aktivitas fisik sedang dan ringan, rerata \pm SD dan kategori asupan natrium (N $=69$ ).

\begin{tabular}{|c|c|c|c|}
\hline & Rerata \pm SD & $\mathrm{n}$ & $\%$ \\
\hline \multicolumn{4}{|l|}{ Kategori usia* } \\
\hline Lansia awal (46-55 tahun) & & 33 & 47,8 \\
\hline Lansia akhir (56-65 tahun) & & 32 & 46,4 \\
\hline Manula ( $\geq 66$ tahun) & & 4 & 5,8 \\
\hline \multicolumn{4}{|l|}{ Tingkat pendidikan } \\
\hline Dasar & & 12 & 17,4 \\
\hline Menengah & & 45 & 65,2 \\
\hline Tinggi & & 12 & 17,4 \\
\hline \multicolumn{4}{|l|}{ Kategori tekanan darah sitolik** } \\
\hline Normal (<120 mmHg) & & 14 & 20,3 \\
\hline Pre-hipertensi (120-139 mmHg) & & 45 & 65,2 \\
\hline Hipertensi $(\geq 140 \mathrm{mmHg})$ & & 10 & 14,5 \\
\hline \multicolumn{4}{|l|}{ Kategori tekanan darah diastolik** } \\
\hline Normal (<80 mmHg) & & 10 & 14,5 \\
\hline Pre-hipertensi (80-89 mmHg) & & 34 & 49,3 \\
\hline Hipertensi ( $\geq 90 \mathrm{mmHg})$ & & 25 & 36,2 \\
\hline \multicolumn{4}{|l|}{ Durasi total aktivitas fisik } \\
\hline <440 menit/minggu & & 34 & 49,3 \\
\hline$\geq 440 \mathrm{menit} / \mathrm{minggu}$ & & 35 & 50,7 \\
\hline Asupan natrium*** & $2319,2 \pm 583,2$ & & \\
\hline Baik (<2400 mg/hari) & & 40 & 58 \\
\hline Tinggi ( $\geq 2400 \mathrm{mg} /$ hari) & & 29 & 42 \\
\hline
\end{tabular}

* Depkes RI tahun 2009

** Joint National Committee (JNC-7): Prevention, Detection, Evaluation, and Treatment of High Blood Pressure (2004).

*** World Health Organization (WHO)

Rentang usia pada penelitian ini adalah 4869 tahun dan modus usia pada penelitian ini adalah 53 tahun $(\mathrm{n}=11)$. Tingkat pendidikan subjek terbanyak ialah menengah $(65,2 \%)$. Prevalensi prehipertensi sistolik sebesar $65,3 \%$ dengan rentang $105-180 \mathrm{mmHg}$ dan tekanan yang terbanyak muncul adalah $120 \mathrm{mmHg}(\mathrm{n}=21)$. Prevalensi prehipertensi diastolik sebesar 49,3\% dengan rentang 70-110 $\mathrm{mmHg}$ dan tekanan yang terbanyak muncul adalah $80 \mathrm{mmHg}(\mathrm{n}=32)$. Beberapa pengakuan subjek saat pengukuran tekanan darah mengatakan bahwa sebelum menopause mereka memiliki tekanan darah yang rendah, dan setelah menopause tekanan darah mereka meningkat dan berhenti pada rentang pre-hipertensi (120-139/80-89 $\mathrm{mmHg})$.

Berdasarkan pengkategorian dari nilai median, 50,7\% ( $\mathrm{n}=35)$ subjek beraktivitas fisik $\geq 440 \mathrm{menit} / \mathrm{minggu}$ atau $\geq 63 \mathrm{menit} / \mathrm{hari}$, yang mencakup kegiatan aktivitas fisik berat, sedang, dan ringan selama atau lebih dari 10 menit per kegiatan. Durasi aktivitas fisik berat didominasi kegiatan mengangkat beban berat. Durasi aktivitas fisik sedang didominasi kegiatan rumah tangga (menyapu, mengepel, mencuci, dan lain-lain). 
Durasi aktivitas fisik ringan didominasi kegiatan adalah durasi kegiatan pekerjaan ruamh tangga.

berjalan. Kontribusi terbesar durasi aktivitas fisik

Tabel 2. Gambaran kegiatan aktivitas fisik subjek

\begin{tabular}{ccc}
\hline Kegiatan aktivitas fisik berat & Kegiatan aktivitas fisik sedang & Kegiatan aktivitas fisik ringan \\
\hline Mengangkat beban berat & Pekerjaan rumah tangga & Berjalan \\
Senam aerobik & Senam & \\
& Berenang & \\
& Jalan cepat pagi & \\
\hline
\end{tabular}

Gambaran asupan natrium subjek adalah $2319,24 \pm 583,16 \mathrm{mg} /$ hari. dengan rentang 908,2$3772,8 \mathrm{mg} /$ hari. Gambaran asupan natrium tersebut dapat di kategorikan baik ( $\leq 2400 \mathrm{mg} /$ hari). namun gambaran asupan natrium tersebut sudah mendekati batas asupan baik dan berdasarkan karakteristik asupan natrium sebanyak 29 subjek $(42,0 \%)$ asupan natriumnya tinggi dan diantaranya terdapat 10 subjek asupan natriumnya diatas 3000 $\mathrm{mg} /$ hari. Subjek pada umumnya tidak menambahkan garam dalam makanan secara berlebihan, jarang atau tidak pernah mengkonsumsi makanan jajanan kemasan maupun minuman ringan (softdrink), namun penambahan kecap, konsumsi gorengan (bakwan dan mendoan) dan konsumsi jeroan (usus) menjadi kontribusi natrium yang cukup sering dikonsumsi.

\section{Uji hubungan durasi aktivitas fisk dengan tekanan darah pada wanita menopause \\ Hasil uji menunjukkan bahwa tidak} terdapat hubungan bermakna antara durasi aktivitas fisik dengan tekanan darah sistolik ( $r=-$ $0,133 ; p=0,275)$ maupun dengan tekanan darah diastolik ( $r=-0,075 ; p=0,541)$.

Uji hubungan asupan natrium dengan tekanan darah pada wanita menopause

Hasil uji menunjukkan bahwa terdapat hubungan bermakna antara asupan natrium dengan tekanan darah sistolik $(r=0,514 ; p=0,000)$, namun tidak terdapat hubungan bermakna asupan natrium dengan tekanan darah diastolik $(r=0,195 ; p=0,108)$. Kedua uji hubungan tersebut menunjukkan koefisien korelasi bernilai positif $(+)$, yang berarti semakin tinggi asupan natrium seseorang makan semakin tinggi pula tekanan darahnya ataupun sebaliknnya.

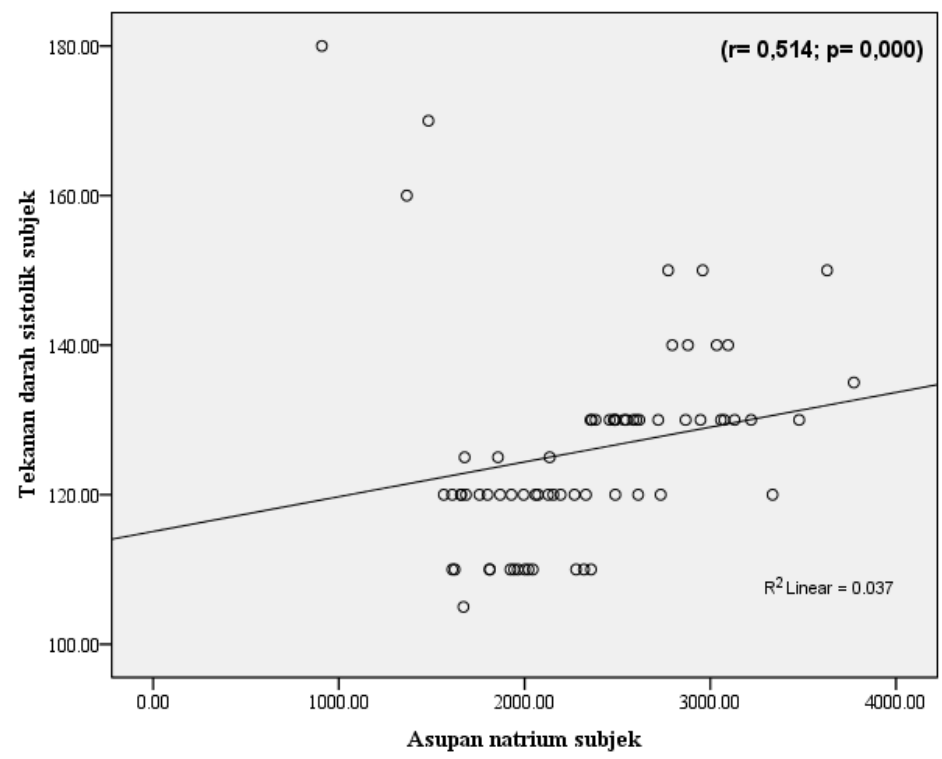

Gambar 1. Diagram tebar hubungan asupan natrium dengan tekanan darah sisstolik ( $N=69)$.

\section{PEMBAHASAN}

Rentang usia subjek yang sudah menopause dalam penelitian ini adalah 48-69 tahun. Hasil laporan Riskesdas 2010 menyatakan masalah haid tidak teratur sudah mulai banyak terjadi pada usia 45-49 tahun $(17,4 \%)$ dan pada usia 50-54 tahun $(17,1 \%)$ kemungkinan terkait dengan usia menopause. $^{12}$ 
Pada umumnya tekanan darah subjek berada pada kategori pre-hipertensi sistolik maupun diastolik. Hasil penelitian yang dilaporkan dalam guidelines Joint National Committee (JNC7): Prevention, Detection, Evaluation, and
Treatment of High Blood Pressure tentang pengaruh menopause terhadap tekanan darah, menunjukkan bahwa wanita menopause memiliki tekanan darah sistolik lebih tinggi 4-5 $\mathrm{mmHg}$ dari yang belum menopause. ${ }^{13}$

Tabel 3. Klasifikasi hipertensi

\begin{tabular}{lccc}
\hline Klasifikasi Hipertensi & $\begin{array}{c}\text { Tekanan Darah Sistolik } \\
(\mathrm{mmHg})\end{array}$ & Tekanan darah diastolik (mmHg) \\
\hline Normal & $<120$ & dan & $<80$ \\
Pre-hipertensi & $120-139$ & atau & $80-89$ \\
Hipertensi 1 & $140-159$ & atau & $90-99$ \\
Hipertensi 2 & $\geq 160$ & atau & $\geq 100$ \\
\hline
\end{tabular}

Joint National Committee (JNC-7): Prevention, Detection, Evaluation, and Treatment of High Blood Pressure (2004).

Berdasarkan uji hubungan, menunjukkan tidak terdapat hubungan bermakna $(p>0,05)$ durasi aktivitas fisik dengan tekanan darah sistolik maupun dengan tekanan darah diastolik. Tidak bermaknanya hubungan tersebut mungkin dikarenakan kontribusi kegiatan durasi aktivitas fisik sedang yang besar, yaitu kegiatan pekerjaan rumah tangga. Pekerjaan rumah tangga yang dapat dikatakan aktivitas fisik intensitas sedang adalah pekerjaan rumah tangga yang dilakukakn secara manual dan benar-benar dilakukan sendiri seperti mencuci tanpa mesin cuci, menyapu atau membersihkan debu tanpa menggunakan vacuum cleaner, melakukan proses memasak dari persiapan hingga penyajian, dan lain-lain, namun dalam hal ini tidak diketahui apakah subjek melakukan pekerjaan rumah tangga yang sesuai dengan aktivitas fisik intensitas sedang.

Aktivitas fisik yang baik untuk menurunkan tekanan darah adalah aktivitas fisik yang mencakup kegiatan berintensitas sedang seperti berjalan cepat, bersepeda sanatai atau senam kesehatan. Laporan penelitan dalam guidelines JNC-7 menyebutkan aktivitas fisik seperti berjalan cepat yang dilakukan minimal 30 menit hampir setiap hari dalam 1 minggu dapat menurunkan tekanan darah sitolik sebanyak 4-9 mmHg. ${ }^{14-15}$ Hasil penelitian melihat beda pengaruh olahraga yang dilakukan pada 207 subjek hipertensi tingkat 1 dan 2 selama 8 minggu dan dibagi 5 kelompok (inaktif individu, 30-61 menit/minggu, 61-90 menit/minggu, 91-120 menit/minggu, $>120 \mathrm{menit} /$ minggu), menunjukkan penurunan tekanan darah sistolik dan diastolik yang signifikan pada kelompok olahraga selama 61-90 menit/minggu, namun tidak terjadi penurunan tekanan darah diastolik yang signifikan pada 4 kelompok lainnya dan tidak ada penurunan yang lebih tinggi pada peningkatan volume olahraga. ${ }^{16}$ Rekomendasi dari The Brazilian Cardiology Society menyarankan untuk melakukan olahraga ringan setidaknya 6 kali seminggu dengan durasi 30-60 menit. ${ }^{17}$ Selain itu, tingkat aktivitas fisik ringan-sedang lebih efektif menurunkan tekanan darah dibanding tingkat berat dan juga lebih efektif pada usia lanjut. ${ }^{4}$

Berdasarkan hasil uji hubungan menunjukkan terdapat hubungan bermakna $(p<0,05)$ asupan natrium dengan tekanan darah sistolik $(r=0,514 ; p=0,000)$. Hasil uji ini sesuai dengan hasil penelitian bertujuan melihat faktor determinan yang berhubungan dengan tekanan darah sitolik, dimana salah satunya adalah asupan natrium, ${ }^{18}$ dan hasil penelitian lain juga menyatakan terdapat hubungan bermakna asupan natrium dengan tekanan darah sitolik $(r=0,483$; $p=0,001) .{ }^{19}$ Selain itu laporan penelitian dalam guidelines $J N C-7$ menyatakan penurunan konsumsi natrium agar tidak lebih dari 2,4 gr natrium per hari atau ( \pm 6 gr garam), dapat menurunkan tekanan darah sitolik sebanyak $2-8 \mathrm{mmHg}^{20-22}$ Namun tidak terdapat hubungan bermakna $(p>0,05)$ asupan natrium dengan tekanan darah diastolik $(p=0.370 r=0,105)$. Hal ini disebabkan tingkat kepekaan individu yang berbeda-beda untuk merespon natrium dan orang yang sudah menderita hipertensi (40-60\%) akan lebih senstif terhadap kelebihan asupan garam (natrium). ${ }^{23}$ Natrium dalam tubuh menyebabkan tubuh menahan air dengan tingkat melebihi batas normal tubuh sehingga dapat meningkatkan volume darah dan menyebabkan tekanan darah meningkat. ${ }^{7}$ Natrium merupakan komponen utama yang aktif dalam perubahan volume caisarn ekstraseluler.. Hampir 
seluruh natrium yang dikonsumsi akan diabsorbsi, terutama di dalam usus halus. Natrium yang diabsorbsi dibawa oleh aliran darah ke ginjal, disaring, dan dieksresi maupun dikembalikan ke aliran darah dalam jumlah yang cukup untuk mempertahankan kadar natrium dalam darah. Secara normal tubuh dapat menjaga keseimbangan antara natrium dan di luar sel dan kalium di dalam sel. $^{7,24-25}$

\section{SIMPULAN}

$65,2 \%$ subjek pre-hipertensi sistolik dan 49,3\% subjek pre-hipertensi diastolik. 14,5\% subjek hipertensi sistolik dan 36,2\% subjek hipertensi diastolik. 50,7\% subjek beraktivitas fisik $\geq 440$ menit/minggu dan kegiatan yang sering dilakukan adalah pekerjaan rumah tangga. Tidak terdapat hubungan bermakana durasi aktivitas fisik dengan tekanan darah sistolik maupun distolik. Gambaran asupan natrium subjek rata-rata baik $(<2400$ $\mathrm{mg} /$ hari). Terdapat hubungan bermakna asupan natrium dengan tekanan darah sistolik.

\section{SARAN}

Untuk mencegah peningkatan tekanan darah pada wanita menopause sebaiknya mengurangi asupan tinggi natrium dan membatasi pada tingkat asupan yang baik yaitu $<2400 \mathrm{mg}$ natrium per hari. Pekerjaan rumah tangga salah satu kegiatan aktivitas fisik intensitas sedang, walupun dilakukan $\geq 30$ menit/hari selama seminggu, namun tidak dapat dipastikan apakah benar-benar termasuk sebagai aktvitas fisik intensitas sedang yang dapat menurunkan tekanan darah. Oleh Karena itu wanita menopause perlu menambah aktivitas fisik intensitas sedang seperti kegiatan berjalan cepat, besepeda santai, atau senam kesehatan yang dilakukan setidaknya 30 menit dan dilakukan minimal 5 hari dalam seminggu.

\section{DAFTAR PUSTAKA}

1. World Health Organization (WHO). Cardiovascular diseases (CVDs). Media Centre [Online] 2012 September [cited 2012 Oct 20]. Available from:URL:

2. http://www.who.int/mediacentre/factsheets/fs317/en/ index.html

3. Clarice Brown, et al. Body Mass Index and the Prevalence of Hypertension and Dyslipidemia. Obes Res. 2000; 8:605-619.

4. Baziad A. Menopause dan Andropause. Jakarta: Yayasan Bina Pustaka Sarwono Prawirodiharjo; 2003. P 112-16.
5. Kokkinos PF, et al. Physical Activity in the Prevention and Management of High Blood Preasure. Hellenic J Cardiol 2009; 50: 52-59.

6. Rahardja EM. Faktor Gizi Dalam Regulasi Tekanan Darah. Ebers Papyrus. 2004;10:165-72.

7. He FJ, MacGregor GA. How far should salt intake be reduced?. Hypertension 2003;42:1093-1099.

8. Charney P. Water, Electrolytes, and Acid Base Balance. In: Krause's Food and utrition Therapy. $12^{\text {th }}$ ed. Canada: Saunders Elsevier 2008. p.150-151.

9. Mahan LK, Sylvia Escott-Stump, editor. Krause's Food, Nutrition and Diet Therapy. $11^{\text {th }}$ ed. Philadelphia: W.B. Saunders Company; 2004.

10. Istiqomah, $Z$ Fitriyah. Kebiasaan konsumsi natrium dan kalium sebagai faktor risiko kejadian hipertensi pada wanita lanjut usia. Jurnal Kesehatan Komunitas Indonesia Vol 6, No 1, 1 Maret 2010.

11. RSU Budi Luhur. Standar Operasional Prosedur (SOP) Pengukuran Tekanan Darah. Buku Standar Asuhan Keperawatan RSU Budi Luhur Jilid 1. Cirebon, Jawa Barat ; 2008 tersedia di:

12. http://www.scribd.com/doc/89612508/20525942Buku-Standar-Asuhan-Keperawatan. diakses tanggal 20 Oktober 2012

13. Dahlan MS. Statistik untuk Kedokteran dan Kesehatan Edisi 3. Jakarta: Salemba Medika; 2008.

14. Balitbangkes. Laporan Nasional Riset Kesehatan Dasar (Riskesdas) Tahun 2010. Jakarta: Depkes RI; 2010.

15. Giles, TD et al. Definition and Classification of Hypertension: An Update. J Clin Hypertens (Greenwich). 2009;11:611-614.

16. Whelton PK, He J, Appel LJ, Cutler JA, Havas S, Kotchen TA, et al. Primary prevention of hypertension: Clinical and public health advisory from The National High Blood Pressure Education Program. JAMA 2002;288:1882-8. in JNC 7 : Compete Report. [cited 2013 Feb 28] Available from:URL:

17. http://www.nhlbi.nih.gov/guidelines/hypertension/jn c7full.pdf

18. Kelley GA, Kelley KS. Progressive resistance exercise and resting blood pressure: A meta-analysis of randomized controlled trials. Hypertension 2000;35:838-43. in JNC 7 : Compete Report. [cited 2013 Feb 28] Available from:URL:

19. http://www.nhlbi.nih.gov/guidelines/hypertension/jn c7full.pdf

20. Takata KI, Ohta T, Tanaka H. How much exercise is required to reduce blood pressure in essential hypertensives: a dose-response study. Am J Hypertens 2003;13:593-600.

21. IV Diretrizes Brasileiras de Hipertensão 2002; cap. 5:13-14 - SBC. in Review Article: Physical exercise and blood pressure control [English Version]. Rev Bras Med Esporte _ Vol. 10, No 6 - Nov/Dez, 2004.

22. Suryandari M. Beberapa Faktor Determinan yang Berhubungan dengan Tekanan Darah Sitolik pada Laki-laki Dewasa di Kota Semarang (Studi di 
kompleks Bina Marga Semarang tahun 2008) [skripsi]. diunduh dari : http://eprints.undip.ac.id/7039/1/3376.pdf . diakses tanggal 20 Febuari 2013.

23. Nurina M. Hubungan konsumsi lemak, Natrium, dan Serat dengan Tekanan Darah Sistolik pada Usia Lanjut Diperumahan Kusumwardani Peleburan kota Semarang [skripsi]. diunduh dari : http://eprints.undip.ac.id/7300/1/2861.pdf. diakses tanggal 20 Febuari 2013.

24. Sacks FM, Svetkey LP, Vollmer WM, Appel LJ, Bray GA, Harsha D, et al. Effects on blood pressure of reduced dietary sodium and the Dietary Approaches to Stop Hypertension (DASH) diet. DASH-Sodium Collaborative Research Group. N Engl J Med 2001;344 :3-10. in JNC 7 : Compete Report. [cited 2013 Feb 28] Available from:URL:

25. http://www.nhlbi.nih.gov/guidelines/hypertension/jn c7full.pdf

26. Vollmer WM, Sacks FM, Ard J, Appel LJ, Bray GA, Simons-Morton DG, et al. Effects of diet and sodium intake on blood pressure: Subgroup analysis of the DASH-sodium trial. Ann Intern Med
2001;135:1019-28. in JNC 7 : Compete Report. [cited 2013 Feb 28] Available from:URL:

27. http://www.nhlbi.nih.gov/guidelines/hypertension/jn c7full.pdf

28. Chobanian AV, Hill M. National Heart, Lung, and Blood Institute Workshop on Sodium and Blood Pressure: A critical review of current scientific evidence. Hypertension 2000;35:858-63. in JNC 7 : Compete Report. [cited 2013 Feb 28] Available from:URL:

29. http://www.nhlbi.nih.gov/guidelines/hypertension/jn c7full.pdf

30. Gropper SS et al. Advanced Nuntrition and Human Metabolism $4^{\text {th }}$ ed.Australia. Thomson Wadsworth; 2005.

31. Sylvia A Price, Wilson LM. Patofisiologi Konsep Klinis Proses-Proses Penyakit. Volume 2 edisi 6. Jakarta: EGC; 2006

32. Horacio JA, Nicolaos EM. Mechanisms of Disease; Sodium and Potassium in the Pathogenesis of Hypertension. The New England Journal of Medicine. 2007; 356: 1977-78. 